\title{
Co-treating mesenchymal stem cells with IL-1及 and TNF- $\alpha$ increases VCAM-1 expression and improves post-ischemic myocardial function
}

\author{
CHUN-MIAO WANG ${ }^{1}$, ZENG GUO ${ }^{1}$, YANG-JING XIE ${ }^{1}$, YU-YU HAO ${ }^{2}$, \\ JI-MIN SUN $^{3}$, JIAN GU ${ }^{4}$ and AI-LING WANG ${ }^{1}$ \\ ${ }^{1}$ Department of Cardiology, The First Affiliated Hospital of Anhui Medical University, Hefei, Anhui 230022; \\ ${ }^{2}$ Department of Emergency, The First People's Hospital of Hefei, Hefei, Anhui 230051; \\ ${ }^{3}$ Department of Pharmacy, The First Affiliated Hospital of Anhui Medical University, Hefei, Anhui 230022; \\ ${ }^{4}$ Department of Cardiology, The First People's Hospital of Hefei, Hefei, Anhui 230051, P.R. China
}

Received September 26, 2013; Accepted March 24, 2014

DOI: $10.3892 / \mathrm{mmr} .2014 .2236$

\begin{abstract}
Inflammatory mediators are released by the myocardium following myocardial ischemia as a response to tissue injury, and contribute to cardiac repair and adaptive responses. Treating mesenchymal stem cells (MSCs) with various inflammatory factors activates a series of biological processes that enhance cell-mediated cardioprotection following myocardial infarction (MI). The present study was designed to examine the effect of interleukin-1 $\beta$ (IL-1 $\beta$ ) and tumor necrosis factor- $\alpha$ (TNF- $\alpha$ ) treatment on vascular cell adhesion molecule-1 (VCAM-1) expression in MSCs, and to identify whether cytokine-treated MSCs improve post-ischemic myocardial function in a rat model. MSCs were stimulated with IL-1 $\beta$ and/or TNF- $\alpha$ for $24 \mathrm{~h}$, the production of vascular cell adhesion molecule-1 (VCAM-1) and the adhesion ability of MSCs were assessed by flow cytometry, adhesion assays, quantitative polymerase chain reaction and western blot analysis. The cardiac function was examined by two-dimensional echocardiography. The results demonstrated that in treated MSCs, the secretion of VCAM-1 and the cell adhesion ability were significantly increased, thus markedly improving cardiac function compared with that of the control group $(\mathrm{P}<0.01)$. Of all the groups, the rats stimulated with a combination of IL- $1 \beta$ and TNF- $\alpha$ exhibited the greatest cardiac improvements. However, there was no significant difference between the 10 and $20 \mathrm{ng} / \mathrm{ml}$ groups which were stimulated with one of the cytokines alone $(\mathrm{P}>0.05)$. In conclusion, stimulating MSCs with IL-1 $\beta$ and TNF- $\alpha$ promoted the expression of VCAM-1
\end{abstract}

Correspondence to: Professor Ai-Ling Wang, Department of Cardiology, The First Affiliated Hospital of Anhui Medical University, 218 Jixi Road, Hefei, Anhui 230022, P.R. China

E-mail:wal@ah.edu.cn

Key words: mesenchymal stem cells, inflammatory cytokine, vascular cell adhesion molecule-1, myocardial ischemia and improved post-ischemic cardiac function recovery. Treating MSCs with two cytokines in combination may be a useful method to maximize the potential of cell-based therapy for MI.

\section{Introduction}

As a novel therapeutic strategy to prevent or reverse ventricular remodeling, heart failure, arrhythmias and myocardial infarction, mesenchymal stem cell (MSC)-based cell therapy replaces endogenous myocardial repair as an improved approach with marked potential (1-3). However, this approach has a number limitations that restrict its application, including low efficiency of MSCs in colonization, survival and differentiation towards myocardial tissue, and diminished donor cell-function in an ischemia microenvironment following transplantation (4-6). Therefore, it is crucial that studies focus on devising a mechanism to increase the survival of cells following transplantation to areas of ischemia tissue.

The activated inflammatory response and cytokine elaboration following myocardial infarction together contribute to cardiac remodeling and eventual host outcome (7). Cytokines are released immediately following ischemia in order to modulate tissue repair and adaptation. Previous studies revealed that MSCs treated with inflammatory mediators activate a series of pathophysiological processes, including cell survival, cell migration, cell adhesion, chemokine release, induction of angiogenesis and modulation of immune responses (8-10). Several studies have demonstrated that pretreatment of MSCs with cytokines, which were released by the myocardium following ischemic injury, increased MSC-mediated cardioprotection following acute myocardial infarction (AMI) $(11,12)$. Interleukin (IL)-1 $\beta$ and tumor necrosis factor (TNF)- $\alpha$ are not constitutively expressed in normal myocardium; however, their levels markedly increase in the infarct and non-infarct areas following AMI (13).

Cell adhesion molecules and their ligands, extracellular matrix components, chemokines and specialized bone marrow niches all have roles in the precise regulation of MSC adhesion 
to endothelial cells (14). It was reported that VCAM-1 together with its ligand very late antigens-4 (VLA-4) was able to bind to stromal or endothelial cells, which subsequently facilitated stem cell homing (14-16). Furthermore, blockage of VCAM-1 or VLA-4 markedly reduced stem cell migration and adhesion ability $(15,17,18)$. Several investigations have also demonstrated that MSCs treated with appropriate cytokines affect the paracrine of cells and then improve cardioprotection (19-21).

In the present study, MSCs with two representative inflammatory cytokines were stimulated alone or in combination to examine the effect on the expression of VCAM-1 in MSCs and the cardiac protective efficiency of cell-transplantation therapy in a rat model of AMI.

\section{Materials and Methods}

Animals. Male Sprague-Dawley (SD) rats were purchased from the Experimental Animal Center of Anhui Province (Anhui, China). The rats received a $12 \mathrm{~h}$ light and dark cycle everyday, and were kept at $20-25^{\circ} \mathrm{C}$ and $40-70 \%$ humidity. In addition, the rats were fed standard laboratory rodents feed ad libitum. All animals used in the present study received the appropriate care according to the Guide for the Care and Use of Laboratory Animals (NIH publication no. 85-23, revised 1996). The present study was approved by the ethics committee of the Experimental Animal Center of Anhui Province.

MSCs isolation and culture. MSCs were isolated from bone marrow of male SD rats (4-6 weeks old) following the standard procedure with certain modifications (22). In brief, bone marrow cells were collected from the bilateral femurs and tibias by removing the epiphyses, flushing the cavity with Dulbecco's modified Eagle's medium (DMEM) and centrifuging the suspension for $10 \mathrm{~min}$ at $300 \mathrm{x} \mathrm{g}$. The cell pellet was then resuspended and cultured in $25 \mathrm{~cm}^{2}$ culture flasks with complete media containing $10 \%$ fetal bovine serum (HyClone, Logan, UT, USA), at $37^{\circ} \mathrm{C}, 90 \%$ humidity and $5 \%$ $\mathrm{CO}_{2}$. Non-adherent cells in the suspension were discarded following $48 \mathrm{~h}$ and fresh complete medium was added and replaced every 3-4 days thereafter. At $90 \%$ confluence, the cells were trypsinized $(0.25 \%$ trypsin $)$ and passaged at $1: 3$ ratios. Cells were identified by flow cytometry as described previously (23). MSCs between passages three and four were used for the following experiments.

Stimulation of MSCs. MSCs were stimulated for $24 \mathrm{~h}$ with IL-1 $\beta$ (PeproTech, Rocky Hill, NJ, USA; 10 or $20 \mathrm{ng} / \mathrm{ml}$ ), TNF- $\alpha$ (PeproTech; 10 or $20 \mathrm{ng} / \mathrm{ml})$ or IL-1 $\beta$ (10 ng/ml) combined with TNF- $\alpha(10 \mathrm{ng} / \mathrm{ml})$. In the meantime, cells in the control group were incubated in parallel without stimulation. Control and treated cells were used for subsequent experiments. Each experiment was repeated at least three times.

Flow cytometry. The control and treated MSCs were harvested and adjusted to a cell density of $10^{6} / \mathrm{ml}$, then resuspended in $100 \mu 1$ phosphate-buffered saline (PBS; $1 \times 10^{6}$ cells). The cells were then incubated with phycoerythrin (PE)-VCAM-1 (BD Biosciences, Franklin Lakes, NJ, USA) antibody at room temperature for $30 \mathrm{~min}$ in the dark. Following this, the cells were washed twice with PBS and dispersed to make a single cell suspension in $400 \mu \mathrm{l}$ PBS. Labeled cells were assayed using a flow cytometer (BD FACSCalibur; BD Biosciences) and analyzed with FCS4 software (version 1.2.4.1; De Novo Software, Los Angeles, CA, USA). At least 10,000 events were analyzed for each sample.

In vitro adhesion assays. To analyze the MSC adhesion capacity, MSCs $\left(5 \times 10^{4}\right.$ cells/well) were seeded in collagen-coated 24-well plates in $250 \mu \mathrm{l}$ complete medium and incubated for $20 \mathrm{~min}$ as previously described $(8,24)$. The wells were gently washed twice with PBS to remove the non-adherent cells and the adherent cells were counted in six random fields per well under a microscope (magnification, x100). The quantity of cells adhered to the plate reflected the relative adhesion ability of the MSCs.

Quantitative polymerase chain reaction ( $q P C R)$. Total RNA was extracted by using the TRIzol reagent (Invitrogen Life Technologies, Carlsbad, CA, USA), cDNA was obtained using a RevertAid First Strand cDNA Synthesis kit (Thermo Fischer Scientific) and then an amplification reaction was performed according to the manufacturer's instructions. The gene-specific primers were designed using Primer Premier 5 software (Premier, Canada) based on cDNA sequences from Genebank and they were as follows: VCAM-1 forward, 5'-CCA GCG AGG GTC TAC CA-3' and reverse, 5'-ACA GGG CTC AGC GTC AG-3'; $\beta$-actin forward, 5'-GTG GGC GGC CCT AGG CAC CA-3' and reverse, 5'-CTC TTT AAT GTC ACG CAC GAT-3'. A Biometra T-Gradient thermal cycler (Biometra, Göttingen, Germany) was used for PCR. The PCR conditions were as follows: denaturation at $94^{\circ} \mathrm{C}$ for $30 \mathrm{sec}$, annealing at $60^{\circ} \mathrm{C}(\mathrm{VCAM}-1) / 51^{\circ} \mathrm{C}\left(\beta\right.$-actin) for $30 \mathrm{sec}$ and extension at $72^{\circ} \mathrm{C}$ for $40 \mathrm{sec}$ for 35 cycles. The PCR products were electrophoresed on a $1.0 \%$ agarose gel stained with $0.5 \mu \mathrm{g} / \mathrm{ml}$ ethidium bromide. The electrophoresis gel containing the PCR products was scanned using the UVP gel imaging system (JD-801; Jieda, Nanjing, Jiangsu, China). The expression of VCAM-1 mRNA was normalized to the expression of $\beta$-actin mRNA.

Western blot analysis. Western blot analysis of cell lysates was performed as previously described (25), proteins were denatured in Laemmli sample buffer (Beyotime Institute of Biotechnology, Shanghai, China) for $5 \mathrm{~min}$ at $95^{\circ} \mathrm{C}$, samples were separated on $10 \%$ SDS-PAGE and transferred to a polyvinylidene difluoride (PVDF) membrane. Membranes were blocked in 5\% non-fat dried milk in Tris-buffered saline containing 0.05\% Tween-20 (TBST; Sigma, St. Louis, MO, USA) for $2 \mathrm{~h}$ prior to incubation with anti-VCAM-1 (1:1,000; Bioworld Technology, Inc., Minneapolis, MN, USA) overnight at $4^{\circ} \mathrm{C}$ and then conjugated with a secondary antibody, anti-rabbit Immunoglobulin G-horseradish peroxidase (Beyotime Institute of Biotechnology), for $1 \mathrm{~h}$ at room temperature. Membranes were washed three times in TBST and positive bands were detected by the enhanced chemiluminescence kit (Thermo Fischer Scientific). All the protein bands were scanned using Chemi Imager 5500 V2.03 software (Alpha Innotech, San Leandro, CA, USA). Protein band intensities were then analyzed by computerized image analysis system (Gel-Pro analyzer 4 software; Media Cybernetics, Rockville, $\mathrm{MD}, \mathrm{USA}$ ) and equal protein was normalized to $\beta$-actin. 
A

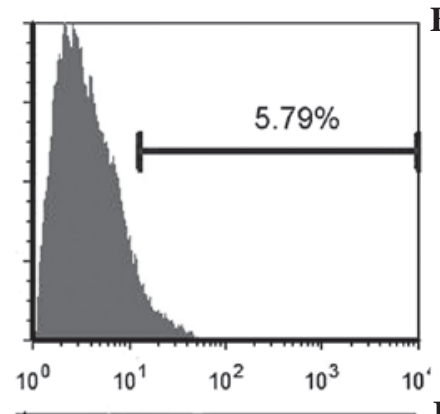

D

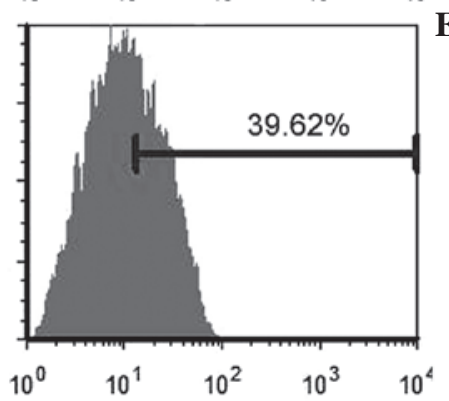

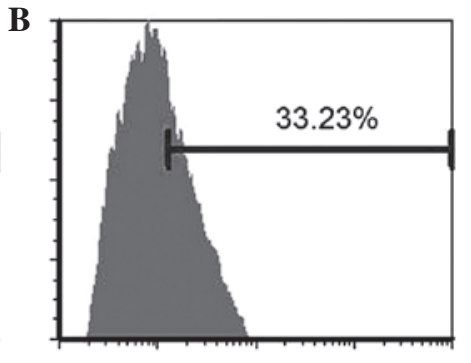

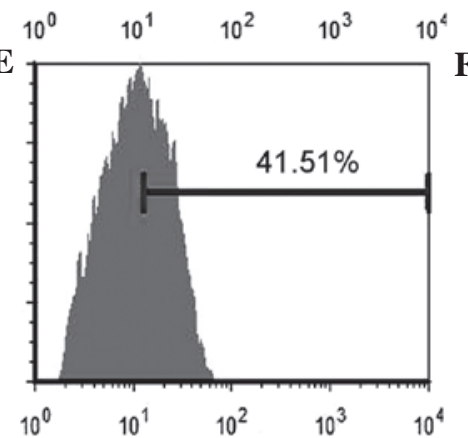

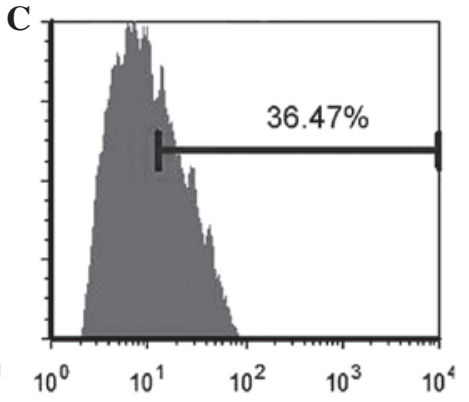

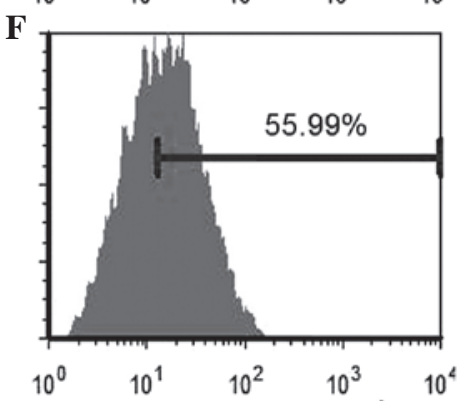

Figure 1. Flow cytometric analysis of VCAM-1. MSCs were stimulated with cytokines for 24 h and the expression of VCAM-1 was quantified by flow cytometry. (A) In the control group, the expression rate of VCAM-1 was 5.79\%. Following stimulation with the cytokines, the expression rates of the adhesion molecule were (B) 33.23 and (C) $36.47 \%$ with IL-1 $\beta$ (10 or $20 \mathrm{ng} / \mathrm{ml}$ ), (D) 39.62 and (E) $41.54 \%$ with TNF- $\alpha$ (10 or $20 \mathrm{ng} / \mathrm{ml}$ ) and (F) $55.99 \%$ in the combination group, respectively. Note the marked increase in VCAM-1 expression. VCAM-1, vascular cell adhesion molecule-1; MSC, mesenchymal stem cells; IL-1 $\beta$, interleukin-1 $\beta$; TNF- $\alpha$, tumor necrosis factor- $\alpha$.

Rat model of AMI and cell transplantation. Myocardial infarction was produced in male SD rats (weighing, 180-220 g) as previously described $(26,27)$. First, a left thoracotomy was performed through the fourth intercostal space to expose the rat heart. Then, the left anterior descending coronary artery (LAD) was ligated with a 6-0 polyester suture. Successful ligation was confirmed by the typical myocardial infarction waves in electrocardiography recordings. The cells were harvested for $1 \mathrm{~h}$ prior to transplantation. The infarcted hearts $(\mathrm{n}=8)$ received intramyocardial injections of $100 \mu \mathrm{l}$ control or treated MSCs $\left(1 \times 10^{6}\right.$ cells). The injections were performed at four different sites in the free wall of the left ventricles.

Assessment of cardiac function. Left ventricular (LV) function was assessed in anesthetized animals four weeks following transplantation of MSCs using two-dimensional echocardiography equipped with a $12-\mathrm{MHz}$ probe (Philips Healthcare, Woerden, Netherlands). The animals were placed on a warming pad in the supine or lateral position. The greatest LV diameter of the internal end-diastole (LVID,d) and internal end-systole (LVID,s) was measured from the long axis view. The LV ejection fraction (LVEF,\%) was calculated as [(LVID,d)3-(LVID,s)3]/(LVID,d)3 x 100. All measurements were averaged on at least three consecutive cardiac cycles and analyzed by an observer blinded to the treatments received by the animals.

Histology. Animals were euthanized prior to isolation and sectioning of their hearts into two transverse slices through the infarct area. The hearts were fixed in $10 \%$ formaldehyde prior to being embedded in paraffin. Sections $(3 \mu \mathrm{m})$ were stained with Masson's trichrome according to the manufacturer's instructions (Maixin, Fuzhou, Fujian, China). Images of each slide were captured with an Olympus BX41 microscope
(Tokyo, Japan). Image-Pro Plus 6.0 (Media Cybernetics, Rockville, MD, USA) was used to evaluate the percentage of myocardial infarction area which exhibited collagen deposition. The percentage of collagen deposition area was calculated as: (Fibrotic area/total LV area) x 100.

Statistical analysis. All values are expressed as the mean \pm standard deviation (SD). Statistical analysis of the results between two groups was performed using a Student's t-test. Differences among the groups were determined by a one-way analysis of variance. The analysis was performed using Prism 5.0 software (GraphPad Software, Inc., La Jolla, CA, USA). $\mathrm{P}<0.05$ was considered to indicate a statistically significant difference between values.

\section{Results}

Flow cytometric analysis. Following the collection and immunostaining of the cells with antibodies, fluorescence was measured by flow cytometry. The results demonstrated the expression of cell surface markers, and that the majority of the cells were positive for CD29 and CD90, while they were negative for CD34. PE-VCAM-1 fluorescence intensities of treated MSCs were markedly increased and had statistical significance when compared with the control group $(\mathrm{P}<0.01)$. The expression of the VCAM-1 was moderately elevated with increasing concentration of the cytokines, but this difference was not statistically significant $(\mathrm{P}>0.05)$. However, co-treatment with the two factors markedly increased the VCAM-1 expression of MSCs as compared with the cells treated with one factor only $(\mathrm{P}<0.01$; Fig. 1).

IL- $1 \beta$ and TNF- $\alpha$ enhance MSC adhesion in vitro. Pre-treatment with IL-1 $\beta$ and TNF- $\alpha$ significantly increased 


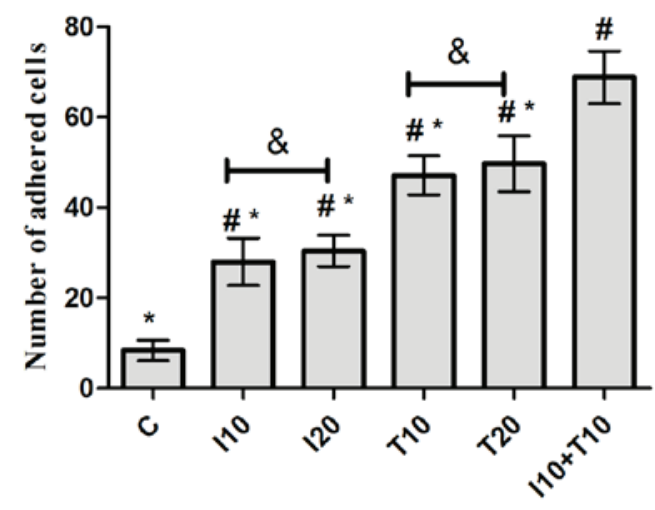

Figure 2. Number of adhered cells. Following treatment with cytokines for $24 \mathrm{~h}$, the number of mesenchymal stem cells that had adhered to the plates was significantly increased. ${ }^{\#} \mathrm{P}<0.01$, compared with the control group; ${ }^{*} \mathrm{P}<0.01$, compared with the combination group; ${ }^{\&} \mathrm{P}>0.05$ compared with the $10 \mathrm{ng} / \mathrm{ml}$ group and $20 \mathrm{ng} / \mathrm{ml}$ group.
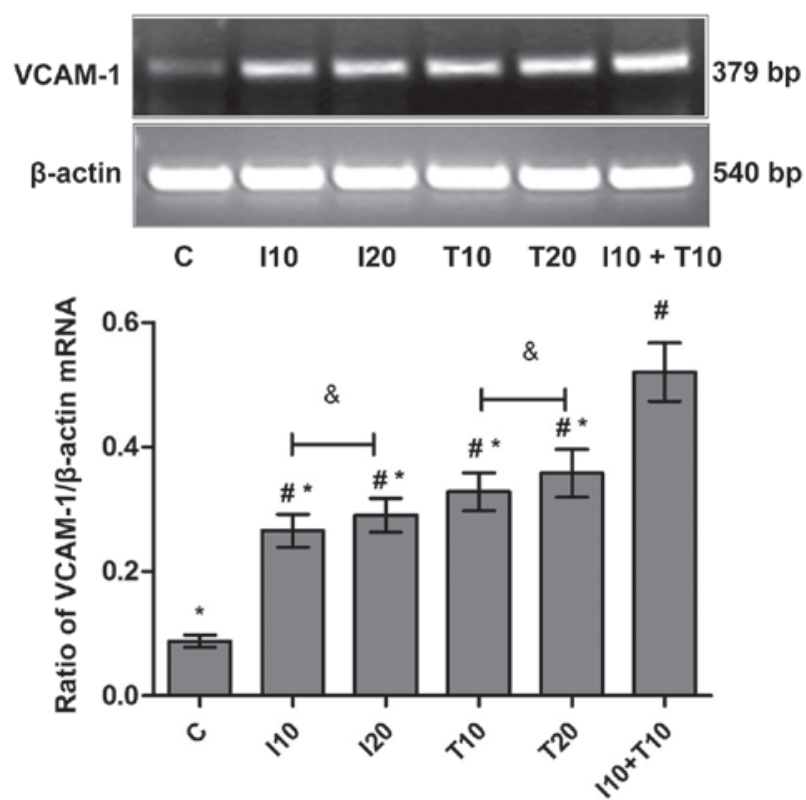

Figure 3. mRNA levels of VCAM-1. (A) Electrophoresis gel of polymerase chain reaction products. (B) Ratio of VCAM- 1 mRNA/ $\beta$-actin mRNA. ${ }^{\text {"}} \mathrm{P}<0.01$, compared with the control group; ${ }^{\mathrm{P}} \mathrm{P}<0.05$, compared with the combination group; ${ }^{\&} \mathrm{P}>0.05$, compared between the $10 \mathrm{ng} / \mathrm{ml}$ and $20 \mathrm{ng} / \mathrm{ml}$ groups. I10/20, treated with $10 / 20 \mathrm{ng} / \mathrm{ml} \mathrm{IL-1 \beta}$; T10/20, treated with $10 / 20 \mathrm{ng} / \mathrm{ml}$ TNF- $\alpha$; I10+T10, treated with $10 \mathrm{ng} / \mathrm{ml}$ IL- $1 \beta$ and TNF- $\alpha$ each; C, control; IL-1 $\beta$, interleukin- $1 \beta$; TNF- $\alpha$, tumor necrosis factor- $\alpha$; VCAM- 1 , vascular cell adhesion molecule-1.

the MSC adhesion ability in vitro $(\mathrm{P}<0.01)$ with responses similar to those of the VCAM-1 expression. Incubation in $20 \mathrm{ng} / \mathrm{ml}$ cytokine moderately increased the number of adhered cells as compared with the $10 \mathrm{ng} / \mathrm{ml}$ treatment group; however, this difference was not statistically significant ( $\mathrm{P}>0.05)$. There were only $8.4 \pm 2.3$ cells adhered to the plate in the control group, but when treated with IL-1 $\beta$, the number of MSCs adhered to the plate increased to $28.0 \pm 5.2$ in the $10 \mathrm{ng} / \mathrm{ml}$ group and $30.4 \pm 3.4 \mathrm{in} 20 \mathrm{ng} / \mathrm{ml}$ group. Similarly, in the TNF- $\alpha$ stimulation groups, the number of MSCs increased from $47.1 \pm 4.3$ in the $10 \mathrm{ng} / \mathrm{ml}$ group to $49.7 \pm 6.2$ in the $20 \mathrm{ng} / \mathrm{ml}$ group. By contrast, the number of adherent cells
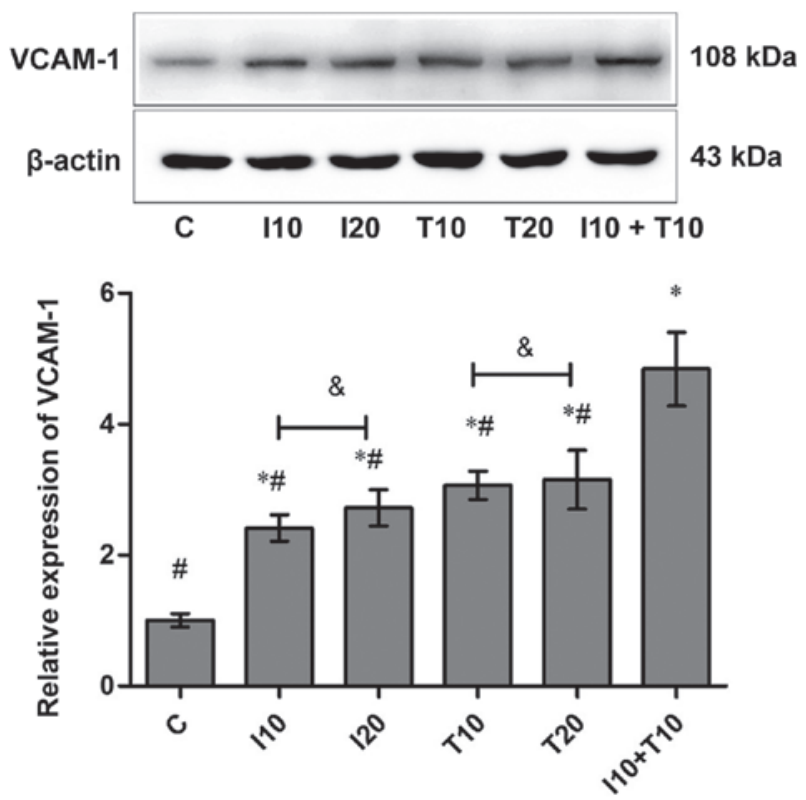

Figure 4. Western blot analysis demonstrating that IL-1 $\beta$ and TNF- $\alpha$ significantly increased the expression of VCAM-1. The protein expression was normalized to $\beta$-actin. ${ }^{~} \mathrm{P}<0.01$, compared with the control group; ${ }^{*} \mathrm{P}<0.05$, compared with the combination group; ${ }^{\&} \mathrm{P}>0.05$, compared between the $10 \mathrm{ng} / \mathrm{ml}$ and $20 \mathrm{ng} / \mathrm{ml}$ groups. I10/20, treated with $10 / 20 \mathrm{ng} / \mathrm{ml} \mathrm{IL-1 \beta ;}$ $\mathrm{T} 10 / 20$, treated with $10 / 20 \mathrm{ng} / \mathrm{ml} \mathrm{TNF}-\alpha$; I10+T10, treated with $10 \mathrm{ng} / \mathrm{ml}$ IL- $1 \beta$ and TNF- $\alpha$ each; C, control; IL-1 $\beta$, interleukin- $1 \beta$; TNF- $\alpha$, tumor necrosis factor- $\alpha$; VCAM-1, vascular cell adhesion molecule-1.

Table I. Effects on heart function four weeks following cell implantation.

\begin{tabular}{lccl}
\hline Group & LVID,d (mm) & LVID,s (mm) & LVEF (\%) \\
\hline C (n=5) & $10.1 \pm 1.0$ & $9.1 \pm 0.9$ & $28.6 \pm 1.5^{*}$ \\
I10 $(\mathrm{n}=6)$ & $9.0 \pm 0.6$ & $7.9 \pm 0.6$ & $33.7 \pm 2.1^{* \# \mathbb{E}}$ \\
I20 $(\mathrm{n}=7)$ & $9.0 \pm 0.7$ & $7.9 \pm 0.6$ & $34.8 \pm 1.7^{* \# \mathbb{E}}$ \\
T10 $(\mathrm{n}=7)$ & $8.4 \pm 0.4$ & $7.0 \pm 0.4$ & $40.9 \pm 2.2^{* \# \$}$ \\
T20 $(\mathrm{n}=7)$ & $8.1 \pm 0.6$ & $6.7 \pm 0.5$ & $43.0 \pm 2.1^{* \text { *\#\$ }}$ \\
I10+T10 $(\mathrm{n}=7)$ & $8.0 \pm 0.4$ & $6.3 \pm 0.4$ & $49.9 \pm 2.4^{\#}$
\end{tabular}

Echocardiographic measurement of LV at the end of the fourth week. Data are presented as the mean \pm standard deviation. ${ }^{\#} \mathrm{P}<0.01$ compared with the control group; ${ }^{*} \mathrm{P}<0.01$ compared with the combination group; ${ }^{\&} \mathrm{P}>0.05$ and ${ }^{\$} \mathrm{P}>0.05$ compared between the $10 \mathrm{ng} / \mathrm{ml}$ and $20 \mathrm{ng} / \mathrm{ml}$ groups. I10/20, treated with $10 / 20 \mathrm{ng} / \mathrm{ml}$ IL-1 $\beta$; T10/20, treated with $10 / 20 \mathrm{ng} / \mathrm{ml} \mathrm{TNF-} \alpha$; I10+T10, treated with $10 \mathrm{ng} / \mathrm{ml}$ IL- $1 \beta$ and TNF- $\alpha$ each; IL- $1 \beta$, interleukin- $1 \beta$; TNF- $\alpha$, tumor necrosis factor- $\alpha$; , control; LVID, d; left ventricular diameter of the internal end-diastole; LVID,s; left ventricular diameter of the internal end-systole; LVEF, left ventricular ejection fraction.

in the combined cytokine treatment group was significantly increased compared with the single cytokine groups $(\mathrm{P}<0.01)$. In the combined cytokine group, the number of MSCs adhered to the plates increased to $68.8 \pm 5.8$ when treated with TNF- $\alpha$ $(10 \mathrm{ng} / \mathrm{ml})$ and IL-1 $\beta$ (10 ng/ml) (Fig. 2).

$I L-1 \beta$ and TNF- $\alpha$ upregulate the gene expression of VCAM-1. qPCR was used to detect VCAM-1 mRNA levels of MSCs. 


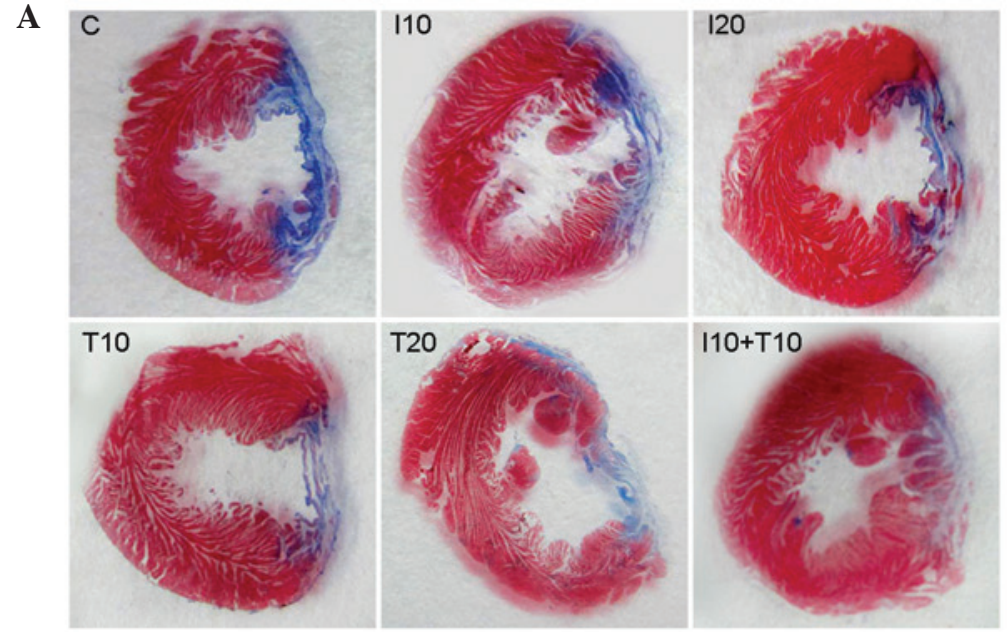

B

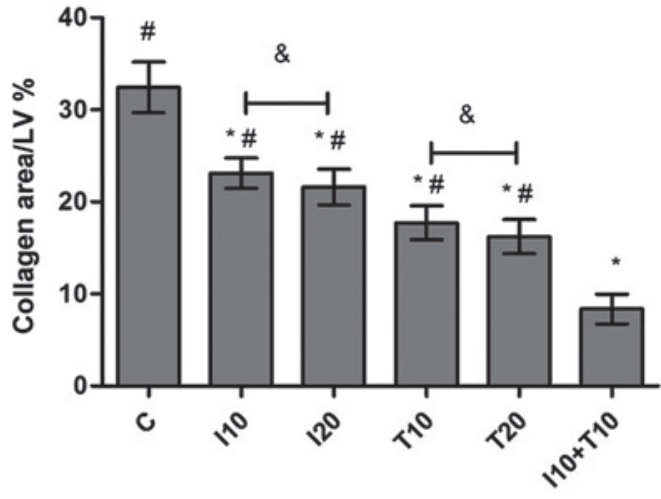

Figure 5. Histological analysis. (A) Representative images of the whole LV for Masson's trichome staining in the different groups. (B) Ratios of blue area in the whole left ventricular wall. " $\mathrm{P}<0.01$, compared with the control group; $\mathrm{P}<0.05$, compared with the combination group; ${ }^{\text {}} \mathrm{P}>0.05$, compared between the different doses (10 or $20 \mathrm{ng} / \mathrm{ml})$. LV, left ventricule; I10/20, treated with 10/20 ng/ml IL-1 $\beta$; T10/20, treated with 10/20 ng/ml TNF- $\alpha$; I10+T10, treated with $10 \mathrm{ng} / \mathrm{ml}$ IL-1 $\beta$ and TNF- $\alpha$ each; C, control; IL-1 $\beta$, interleukin- $1 \beta ;$ TNF- $\alpha$, tumor necrosis factor- $\alpha$.

Following subtraction of the background, VCAM-1 mRNA levels were compared among the different groups relative to the $\beta$-actin mRNA levels. Incubation with IL-1 $\beta$ (10 or $20 \mathrm{ng} / \mathrm{ml}$ ) induced the mRNA expression of VCAM- 1 to $0.27 \pm 0.03$ and $0.29 \pm 0.03$, respectively, compared with $0.09 \pm 0.01$ in the untreated control group. Stimulation with TNF- $\alpha$ (10 or $20 \mathrm{ng} / \mathrm{ml}$ ) induced the transcription of VCAM-1 to $\sim 0.33 \pm 0.03$ and $0.36 \pm 0.04$, respectively. By contrast, exposure of MSCs to IL-1 $\beta(10 \mathrm{ng} / \mathrm{ml})$ and TNF- $\alpha(10 \mathrm{ng} / \mathrm{ml})$ resulted in a marked increase in mRNA synthesis with a value of $0.52 \pm 0.05$ relative to the level of $\beta$-actin mRNA (Fig. 3).

Protein expression of VCAM-1. To further confirm the above results, the protein expression of VCAM-1 was quantified by measuring protein bands which were transferred to a PVDF membrane. In concordance with the flow cytometry results, adhesion experiments and mRNA data, the western blot analysis demonstrated that stimulation with IL-1 $\beta$ and TNF- $\alpha$ induced an evident increase in the VCAM-1 protein expression levels. IL-1 $\beta$ alone (10 ng/ml, 2.4 \pm 0.2 -fold; $20 \mathrm{ng} / \mathrm{ml}, 2.7 \pm 0.3$-fold), TNF- $\alpha$ alone ( $10 \mathrm{ng} / \mathrm{ml}, 3.1 \pm 0.2$-fold; $20 \mathrm{ng} / \mathrm{ml}, 3.2 \pm 0.4$-fold) and combination of the two cytokines (4.8 \pm 0.6 -fold) markedly increased the protein expression of VCAM-1 in MSCs in vitro (Fig. 4).

Measurement of heart function. To examine the therapeutic efficacy of treated MSCs in MI in vivo, the cells were transplanted into the border region between the infarcted and normal area of rat hearts following coronary ligation. At the end of the fourth week following surgery, nine of the rats had not survived the experiment, three of them in the control group, two in the IL-1 $\beta(10 \mathrm{ng} / \mathrm{ml})$ group and the other four were one for each group. The LVID,d and LVID,s of the heart was measured and then the LVEF was calculated (Table I). The LVEFs of the stimulation groups were evidently improved as compared with the control group $(28.6 \pm 1.5 \%)$ and the specific measurement results were as follows: The LVEFs in the 10 and $20 \mathrm{ng} / \mathrm{ml} \mathrm{IL-1 \beta}$ groups were $33.7 \pm 2.1$ and $34.8 \pm 1.7 \%$, respectively, in the 10 and $20 \mathrm{ng} / \mathrm{ml} \mathrm{TNF-} \alpha$ groups they were $40.9 \pm 2.2$ and $43.0 \pm 2.1 \%$, respectively, and in the co-treatment group, the LVEF was $49.9 \pm 2.4 \%$.

Histological changes. To further verify the myocardial protection effect in vivo, the cardiac slices were stained with Masson's trichrome. The non-infarcted left ventricular appeared red, while the infarcted myocardium replaced with fibroblasts and collagen appeared blue. The measurements revealed that the myocardial infarct size in both the IL-1 $\beta(10 \mathrm{ng} / \mathrm{ml}, 23.11 \pm 1.64$; $20 \mathrm{ng} / \mathrm{ml}, 21.61 \pm 1.94 \%)$ and TNF- $\alpha(10 \mathrm{ng} / \mathrm{ml}, 17.71 \pm 1.85 \%$; $20 \mathrm{ng} / \mathrm{ml}, 16.23 \pm 1.85 \%$ ) groups was notably reduced compared with the control group $(32.44 \pm 2.74 \%$; $\mathrm{P}<0.01)$. Furthermore, the infarct size was even more reduced in the cytokine combination treatment group $(8.37 \pm 1.60 \%)$. However, there was no significant difference between the infarct size in the hearts of the $20 \mathrm{ng} / \mathrm{ml}$ and $10 \mathrm{ng} / \mathrm{ml}$ cytokine stimulation groups ( $\mathrm{P}>0.05$; Fig. 5).

\section{Discussion}

In the present study, it was identified that IL- $1 \beta$ and TNF- $\alpha$ stimulation significantly elevated the VCAM-1 secretion and adhesion ability of MSCs, and the combination of these two cytokines potentiated this effect. Furthermore, intramyocardial injection with MSCs which were pretreated with IL-1 $\beta$ and TNF- $\alpha$ markedly improved the myocardial function and decreased the collagen deposition in infarcted myocardium in rats. Cytokine concentrations of 10 and $20 \mathrm{ng} / \mathrm{ml}$ were selected as the appropriate stimulation concentrations, as these concentrations were previously shown to activate paracrine signaling without changing surface makers or the viability of MSCs $(28,29)$.

Previous studies have indicated that homing of circulating stem cells within the myocardium is possibly the first step of the myocardial regeneration process. This step requires adhesion of stem cells to the cardiac microvascular endothelium (15). Adhesion molecules are cell surface proteins that mediate the 
inter-communication between cells, or between the cells and the extracellular matrix (ECM). Several investigations have demonstrated that VCAM-1 has a key role in MSC-mediated adhesion and immunosuppression $(15,24)$. VCAM-1 is also important in the adhesion and migration of leukocytes through brain microvascular endothelial cells via binding to the $\alpha 4 \beta 1$ and $\alpha 4 \beta 7$ integrins $(30,31)$. In previous studies, the adhesion of MSCs to endothelial cells was significantly eliminated following incubation with monoclonal blocking antibodies against VCAM-1. By contrast, it had only a weak and non-significant effect when the ICAM-1 antibody was added $(15,24)$. In the present study, using an adhesion assay, the crucial role of VCAM-1 on MSCs adhesion was confirmed. Following the addition of cytokines, the quantity of cell adhesion to the plate markedly increased along with the upregulation of the adhesion molecule.

A number of investigators have suggested that intramyocardial MSC transplantation recruits a number of inflammatory factors which contribute to cardiac remodeling $(32,33)$. Several studies have demonstrated that the cardioprotective effect of MSCs may be regulated by mediators which are secreted by stem cells. Together with these mediators, stem cells promoted tissue repair and elicited other beneficial effects (34-36). Tsoyi et al (37) and Ward et al (38) reported that PI3K participated in the regulation of VCAM-1 expression and in intracellular signal transduction of the cell migration, which were induced by TNF- $\alpha$ in human endothelial cells. Other studies suggested that IL-1 $\beta$ induced MSC migration and adhesion through NF-кb (8). Since stem cells are consistently exposed to the inflammatory environment following implantation to ischemic areas, these inflammatory cytokines are critical for MSC behavior. Investigating the response of MSCs to an inflammatory environment will be undoubtedly valuable for improving transplantation efficiency.

Following the above rationale, MSCs were cultured in the presence of two typical inflammatory mediators, IL-1 $\beta$ and TNF- $\alpha$, and administered to rats following experimentally-induced myocardial ischemic injury. The expression of VCAM-1 and the cardiac function of the left ventricular region were then assessed. It was identified that the expression of the adhesion molecule significantly increased following treatment with either of the cytokines, as did the cardiac function of the rats. As a number of investigations have demonstrated that the effect of inflammatory cytokines activating stem cell paracrine exhibited a dose-dependent trend $(2,29)$, the dosage of the cytokines was doubled. Stimulation of MSCs with $20 \mathrm{ng} / \mathrm{ml}$ IL-1 $\beta$ or TNF- $\alpha$ did elevate the VCAM-1 protein expression and the quantity of plate-adhered cells compared with the $10 \mathrm{ng} / \mathrm{ml}$-treated group; however, the difference was not statistically significant. Of note, the combination of the two cytokines induced more beneficial effects than the doubled dose alone. It is necessary to lower the dosage of the cytokines, but maintain a high level of VCAM-1 and the adhesion ability of the MSCs, as well as to avoid unwanted adversary effects to the MSCs or heart during the treatment.

There are a number limitations to be addressed in the present study. Due to the persistence of inflammatory factors in the myocardium during infarction, it remains unclear whether the complicated microenvironment would affect the treated MSCs. Furthermore, the present study did not investigate the mechanism underlying the effects of the combination of the two cytokines. Further studies are required to examine the underlying mechanisms and other biological behaviors of MSCs in the inflammatory environment, so as to fully elucidate their potential of cell-based therapies for MI.

\section{Acknowledgments}

This study was supported by the Research Grants Council of Anhui Province (no. 11040606M155) and by the School of Life Sciences, University of Science and Technology of China.

\section{References}

1. Schulman IH and Hare JM: Key developments in stem cell therapy in cardiology. Regen Med 7 (6 Suppl): 17-24, 2012.

2. Luo Y, Wang Y, Poynter JA, et al: Pretreating mesenchymal stem cells with interleukin-1 $\beta$ and transforming growth factor- $\beta$ synergistically increases vascular endothelial growth factor production and improves mesenchymal stem cell-mediated myocardial protection after acute ischemia. Surgery 151: 353-363, 2012.

3. Zheng Z,Leng Y,Zhou C, Ma Z,Zhong Z, Shi XM and Zhang W: Effects of matrix metalloproteinase-1 on the myogenic differentiation of bone marrow-derived mesenchymal stem cells in vitro. Biochem Biophys Res Commun 428: 309-314, 2012.

4. Herrmann JL, Weil BR, Abarbanell AM, Wang Y, Poynter JA, Manukyan MC and Meldrum DR: IL- 6 and TGF- $\alpha$ costimulate mesenchymal stem cell vascular endothelial growth factor production by ERK-, JNK-, and PI3K-mediated mechanisms. Shock 35: 512-516, 2011.

5. Cui X, Wang H, Guo H, Wang C, Ao H, Liu X and Tan YZ: Transplantation of mesenchymal stem cells preconditioned with diazoxide, a mitochondrial ATP-sensitive potassium channel opener, promotes repair of myocardial infarction in rats. Tohoku J Exp Med 220: 139-147, 2010.

6. Zhang M, Methot D, Poppa V, Fujio Y, Walsh K and Murry CE: Cardiomyocyte grafting for cardiac repair: graft cell death and anti-death strategies. J Mol Cell Cardiol 33: 907-921, 2001.

7. Nian M, Lee P, Khaper N and Liu P: Inflammatory cytokines and postmyocardial infarction remodeling. Circ Res 94: 1543-1553, 2004.

8. Carrero R, Cerrada I, Lledó E, et al: IL1 $\beta$ induces mesenchymal stem cells migration and leucocyte chemotaxis through NF-кB. Stem Cell Rev 8: 905-916, 2012.

9. Fan H, Zhao G, Liu L, et al: Pre-treatment with IL-1 $\beta$ enhances the efficacy of MSC transplantation in DSS-induced colitis. Cell Mol Immunol 9: 473-481, 2012.

10. Heo SC, Jeon ES, Lee IH, Kim HS, Kim MB and Kim JH: Tumor necrosis factor- $\alpha$-activated human adipose tissue-derived mesenchymal stem cells accelerate cutaneous wound healing through paracrine mechanisms. J Invest Dermatol 131: 1559-1567, 2011.

11. Kim YS, Park HJ, Hong MH, et al: TNF-alpha enhances engraftment of mesenchymal stem cells into infarcted myocardium. Front Biosci (Landmark Ed) 14: 2845-2856, 2009.

12. Herrmann JL, Abarbanell AM, Weil BR, et al: Postinfarct intramyocardial injection of mesenchymal stem cells pretreated with TGF-alpha improves acute myocardial function. Am J Physiol Regul Integr Comp Physiol 299: R371-R378, 2010.

13. Deten A, Volz HC, Briest W and Zimmer HG: Cardiac cytokine expression is upregulated in the acute phase after myocardial infarction. Experimental studies in rats. Cardiovasc Res 55: 329-340, 2002.

14. Chute JP: Stem cell homing. Curr Opin Hematol 13: 399-406, 2006.

15. Segers VF, Van Riet I, Andries LJ, et al: Mesenchymal stem cell adhesion to cardiac microvascular endothelium: activators and mechanisms. Am J Physiol Heart Circ Physiol 290: H1370-H1377, 2006. 
16. Balzer EM and Konstantopoulos K: Intercellular adhesion: mechanisms for growth and metastasis of epithelial cancers. Wiley Interdiscip Rev Syst Biol Med 4: 171-181, 2012.

17. Bonig H, Priestley GV and Papayannopoulou T: Hierarchy of molecular-pathway usage in bone marrow homing and its shift by cytokines. Blood 107: 79-86, 2006.

18. Hu Y, Cheng P, Xue YX and Liu YH: Glioma cells promote the expression of vascular cell adhesion molecule-1 on bone marrow-derived mesenchymal stem cells: a possible mechanism for their tropism toward gliomas. J Mol Neurosci 48: 127-135, 2012.

19. Wang Y, Crisostomo PR, Wang M, Markel TA, Novotny NM and Meldrum DR: TGF-alpha increases human mesenchymal stem cell-secreted VEGF by MEK- and PI3-K- but not JNK- or ERK-dependent mechanisms. Am J Physiol Regul Integr Comp Physiol 295: R1115-R1123, 2008.

20. Herrmann JL, Abarbanell AM, Wang Y, Weil BR, Poynter JA, Manukyan MC and Meldrum DR: Transforming growth factor- $\alpha$ enhances stem cell-mediated postischemic myocardial protection. Ann Thorac Surg 92: 1719-1725, 2011.

21. Böcker W, Docheva D, Prall WC, et al: IKK-2 is required for TNF-alpha-induced invasion and proliferation of human mesenchymal stem cells. J Mol Med (Berl) 86: 1183-1192, 2008.

22. Tropel P, Noël D, Platet N, Legrand P, Benabid AL and Berger F: Isolation and characterisation of mesenchymal stem cells from adult mouse bone marrow. Exp Cell Res 295: 395-406, 2004.

23. Wang A, Shen F, Lang Y and Wang J: Marrow-derived MSCs and atorvastatin improve cardiac function in rat model of AMI. Int J Cardiol 150: 28-32, 2011.

24. Ren G, Roberts AI and Shi Y: Adhesion molecules: key players in mesenchymal stem cell-mediated immunosuppression. Cell Adh Migr 5: 20-22, 2011.

25. Kim HJ, Lee SI, Lee DH, Smith D, Jo H, Schellhorn HE and Boo YC: Ascorbic acid synthesis due to L-gulono-1,4-lactone oxidase expression enhances NO production in endothelial cells Biochem Biophys Res Commun 345: 1657-1662, 2006.

26. Niagara MI, Haider HKh, Jiang $S$ and Ashraf $M$ : Pharmacologically preconditioned skeletal myoblasts are resistant to oxidative stress and promote angiomyogenesis via release of paracrine factors in the infarcted heart. Circ Res 100: $545-555,2007$
27. Mias C, Lairez O, Trouche E, et al: Mensenchymal stem cells promote matrix metalloproteinase secretion by cardiac fibroblasts and reduce cardiacventricular fibrosis after myocardial infarction. Stem Cells 27: 2734-2743, 2009.

28. Xiao Q, Wang SK, Tian H, et al: TNF- $\alpha$ increases bone marrow mesenchymal stem cell migration to ischemic tissues. Cell Biochem Biophys 62: 409-414, 2012.

29. Thankamony SP and Sackstein R: Enforced hematopoietic cell E- and L-selectin ligand (HCELL) expression primes transendothelial migration of human mesenchymal stem cells. Proc Natl Acad Sci USA 108: 2258-2263, 2011.

30. Hyun YM, Chung HL, McGrath JL, Waugh RE and Kim M: Activated integrin VLA-4 localizes to the lamellipodia and mediates T cell migration on VCAM-1. J Immunol 183: 359-369, 2009.

31. Yilmaz G and Granger DN: Leukocyte recruitment and ischemic brain injury. Neuromolecular Med 12: 193-204, 2010.

32. Armiñán A, Gandía C, García-Verdugo JM, et al: Mesenchymal stem cells provide better results than hematopoietic precursors for the treatment of myocardial infarction. J Am Coll Cardiol 55: 2244-2253, 2010.

33. Kawada H,Fujita J, Kinjo K, et al: Nonhematopoietic mesenchymal stem cells can be mobilized and differentiate into cardiomyocytes after myocardial infarction. Blood 104: 3581-3587, 2004.

34. Horwitz EM and Prather WR: Cytokines as the major mechanism of mesenchymal stem cell clinical activity: expanding the spectrum of cell therapy. Isr Med Assoc J 11: 209-211, 2009.

35. Shake JG, Gruber PJ, Baumgartner WA, et al: Mesenchymal stem cell implantation in a swine myocardial infarct model: engraftment and functional effects. Ann Thorac Surg 73: 1919-1925, 2002.

36. Mangi AA, Noiseux N, Kong D, et al: Mesenchymal stem cells modified with Akt prevent remodeling and restore performance of infarcted hearts. Nat Med 9: 1195-1201, 2003.

37. Tsoyi K, Jang HJ, Nizamutdinova IT, et al: PTEN differentially regulates expressions of ICAM-1 and VCAM-1 through PI3K/Akt/GSK-3//GATA-6 signaling pathways in TNF- $\alpha$-activated human endothelial cells. Atherosclerosis 213: 115-121, 2010.

38. Ward SG, Westwick J and Harris S: Sat-Nav for T cells: role of PI3K isoforms and lipid phosphatases in migration of $\mathrm{T}$ lymphocytes. Immunol Lett 138: 15-18, 2011. 